\title{
Peran Konektivitas Dalam Pembangunan Ekonomi Kepulauan Provinsi Maluku Utara
}

\author{
Yetty $^{1}$, Chairullah Amin ${ }^{2}$, Zulkifli Waibot ${ }^{3}$ \\ 1,2,3 Jurusan Ekonomi Pembangunan Universitas Khairun
}

Received: Maret 2021; Accepted: Maret 2021; Published: Maret 2021

\begin{abstract}
Abstrak
Penelitian ini menekankan pentingnya peran konektivitas dalam pembangunan ekonomi wilayah kepulauan Provinsi Maluku Utara. Metode penelitian menggunakan teknik analisis jalur untuk menjelaskan hubungan sebab akibat variabel konektivitas, inflasi, pertumbuhan ekonomi, dan kemiskinan. Dengan menggunakan data sekunder, hasil menunjukkan terdapat hubungan negatif antara inflasi dengan pertumbuhan ekonomi, hubungan positif konektivitas dengan pertumbuhan ekonomi, hubungan negatif antar pertumbuhan ekonomi dengan kemiskinan, dan hubungan negatif antar konektivitas dengan kemiskinan. Hasil ini menegaskan bahwa pengembangan konektivitas di wilayah pulau-pulau kecil dan kepulauan adalah upaya untuk menyelesaikan permasalahan ekonomi masyarakat pulau yang memiliki tingkat kerentanan yang tinggi dalam pembangunan ekonominya.
\end{abstract}

Kata kunci: Inflasi, Konektivitas, Pertumbuhan Ekonomi, Kemiskinan.

\begin{abstract}
The study emphasizes the importance of connectivity in the economic development of the islands of North Maluku province. The research method uses path analysis techniques to explain the causal relationship between connectivity variables, inflation, economic growth, and poverty. The results show a negative relationship between inflation and economic growth, a positive relationship with economic growth, a negative relationship between economic growth and poverty, and a negative relationship between connectivity and poverty. The results emphasize the importance of developing connectivity in archipelagic areas with a high level of vulnerability in their economic development.
\end{abstract}

Keywords: Inflation, Poverty, Connectivity, Economic Growth

How to Cite: Yetty., Amin, C., Waibot, Z., (2021). Peran Konektivitas Dalam Pembangunan Ekonomi Kepulauan Provinsi Maluku Utara JFRES: Journal of Fiscal and Regional Economy Studies, 2 (2), $50-60$.

\footnotetext{
Corresponding author :

E-mail: y.tarumadoja@gmail.com
} 


\section{PENDAHULUAN}

Karakteristik wilayah mempunyai pengaruh kuat pada terciptanya pola pembangunan ekonomi, sehingga pola pembangunan ekonomi di Indonesia juga tidak seragam. Ketidakseragaman ini berpengaruh pada kemampuan untuk tumbuh, yang mengakibatkan beberapa wilayah mampu tumbuh dengan cepat sementara wilayah lainnya tumbuh lambat. Kemampuan tumbuh yang berbeda ini pada akhirnya menyebabkan terjadinya ketimpangan baik pembangunan maupun hasilnya, yakni pendapatan antar daerah.

Pembangunan wilayah yang didalamnya terdapat aspek penting pengurangan ketimpangan wilayah membutuhkan kebijakan-kebijakan yang tepat dari pemerintah. Pembangunan infrastruktur menjadi prioritas utama Pemerintah untuk meningkatkan daya saing dan mengurangi kesenjangan antar wilayah serta kesenjangan sosial ekonomi masyarakat dengan meningkatkan konektivitas antar wilayah. Menurut Sukwika (2018) faktor yang mendorong ketimpangan salah satunya adalah perbedaan pembangunan infrastruktur antar wilayah. Pertumbuhan ekonomi menuntut ketersediaan sarana dan prasarana pendukung untuk mendorong peningkatan produktifitas dan investasi. Hal ini menunjukkan hubungan yang erat antara pembangunan infrastruktur dengan ekonomi.

Pembangunan jalan dan jembatan antar wilayah membuka keterisolasian dan menggerakan perekonomian dengan transportasi dan lancarnya transaksi perdagangan ke daerah lain (Prahara, 2010). Dengan aksesbilitas yang baik, maka kesempatan berkembang bagi wilayah tertinggal menjadi lebih besar. Harmes (2018) menyatakan bahwa pada wilayah dengan aksesibilitas tinggi, maka kemiskinan cenderung rendah. Wilayah dengan akses tinggi ditunjukkan dengan banyaknya jaringan jalan di wilayah tersebut sehingga dapat menurunkan biaya ekonomi masyarakat ketika melakukan aktifitas. Kegiatan infrastruktur tidak hanya akan menciptakan lapangan kerja, namun keberadaanya mempengaruhi efisiensi dan kelancaran ekonomi di sektor-sektor lainnya (Wahyuni, 2011).

Sebagai pusat pertumbuhan ekonomi baru, Maluku Utara membutuhkan beberapa syarat sehingga daerah ini bisa maju dan berkembang. Keterbatasan akses dan hubungan dengan daerah lain yang sudah lebih maju sangat mempengaruhi daerah terbelakang untuk bisa mengikuti kemajuan yang terjadi. Sarana infrastruktur dalam segala hal akan sangat membantu kemajuan daerah ekonomi baru tersebut. Sehingga salah satu syarat untuk mendorong kemajuan pembangunan di pusat ekonomi baru tersebut adalah dengan mengembangkan jalur konektivitas ekonomi antar daerah atau antar pulau di dalam wilayah Malut dengan daerah atau pulau yang lebih maju di luar Malut.

Kunci untuk konektivitas di dalam pulau di Malut adalah terletak pada menghubungkan daerah pedesaan dengan daerah perkotaan, menghubungkan daerah pedesaan ke kutub pertumbuhan di pulau tersebut serta yang terpenting adalah menghubungkan kutub-kutub pertumbuhan tersebut. Peningkatan konektivitas antar pulau tidak hanya terkait dengan biaya transportasi dan pengiriman, tetapi juga berbagai jenis sistem transportasi, yang mencakup fasilitas transportasi darat, laut, sungai dan udara. Hal ini harus direncanakan secara teliti untuk mencegah tumpang tindih dan ketidakefisienan yang menghabiskan biaya.

Masalah inflasi di Provinsi Maluku Utara merupakan salah satu kendala bagi pembangunan ekonomi daerah. Inflasi yang tinggi sangat tidak menguntungkan terutama bagi kalangan industry, pengusaha atau investor yang ingin menanamkan modal investasi disektor-sektor ekonomi yang menjanjikan seperti sektor perikanan, pertambangan, perdagangan dan jasa. Provinsi Maluku Utara khususnya Kota Ternate merupakan salah satu daerah atau kota dengan tingkat inflasi yang tertinggi di Indonesia dan juga berbiaya ekonomi tinggi (high economic cost). Gambaran tingkat inflasi di Provinsi Maluku Utara dapat dilihat pada gambar 1.

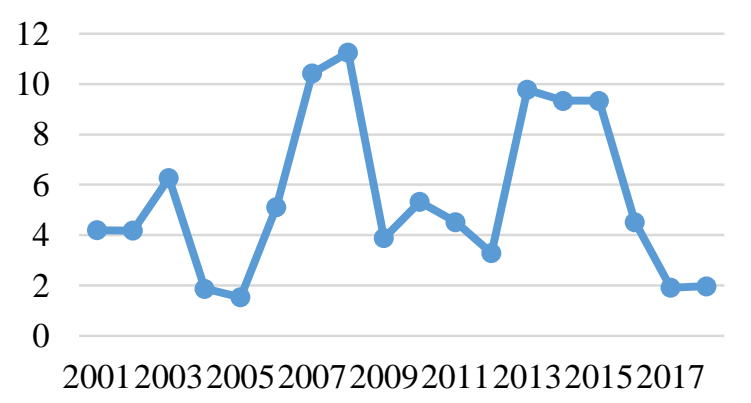

Sumber: BPS Malut, 2001-2018

Gambar 1. Tingkat Inflasi Provinsi Maluku Utara 2001-2018 
Selama periode 2001 hingga tahun 2018 inflasi di Provinsi Malut cukup berfluktuasi. Inflasi tertinggi terjadi pada tahun 2008 yaitu sebesar $11.25 \%$ dan inflasi terendah terjadi pada tahun 2012 sebesar 3,29\%. Namun inflasi kemudian merangkak naik kembali pada tahun 2013 sebesar 9,78\%. Kenaikan ini disebabkan oleh beberapa faktor diantaranya yaitu pasokan suplai barang yang terganggu, biaya transportasi yang naik, lesuhnya perdagangan secara nasional serta faktor kenaikan harga BBM. Namun secara rata-rata inflasi di provinsi Malut sebesar 6.78\%. Angka ini masih tergolong rendah jika dibandingkan dengan provinsi Papua yang mencapai $8 \%$. Kondisi kepulauan yang harus dijangkau dengan kapal dan speed menjadi hambatan tersendiri, jika kondisi cuaca lagi baik maka tidak akan mengganggu pasokan suplai namun jika cuaca memburuk maka dapat dipastikan pasokan suplai makanan dan kebutuhan pokok lainnya akan terganggu.

Menurut Behrens (2007), kata wilayah digunakan untuk menggambarkan sekumpulan tempat yang memiliki karakteristik tertentu yang berada dalam suatu daerah yang sama atau dapat juga dipahami sebagai satu set daerah yang meliputi bagian dari beberapa wilayah geografis yang terdiri dari sejumlah besar tempat yang menjadi unit spasial dasar. Wilayah dapat juga diartikan sebagai suatu area geografis yang memiliki ciri tertentu dan merupakan media untuk segala sesuatu untuk berlokasi dan berinteraksi. Kata ciri tertentu memiliki arti penting dan kritis karena berkaitan dengan fungsi yang menjadi tujuan dari suatu upaya perwilayahan atau dibentuknya suatu wilayah (Nugroho dan Dahuri, 2004).

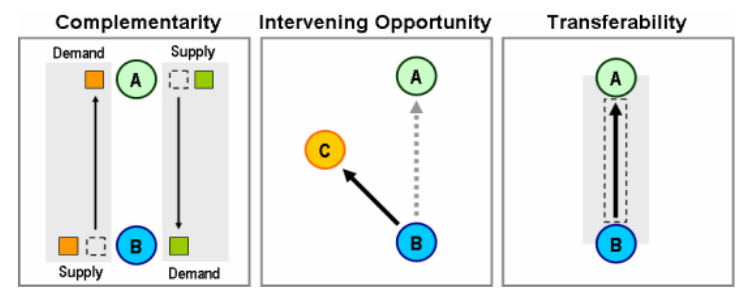

Sumber: Ulman, 1956

Gambar 2. Karakteristik Hubungan Antar

Wilayah

Wilayah atau region digunakan sebagai penekanan atas adanya karakteristik hubungan dari fungsi-fungsi dan komponen didalam suatu unit wilayah sehingga batas dan sistemnya sangat ditentukan oleh aspek fungsional tersebut (Rustiadi, 2007). Sedangkan menurut Losch
(1938) wilayah dapat diartikan sebagai suatu gambaran sekumpulan tempat dimana terdapat dua tempat yang berada pada wilayah yang sama atau berada pada wilayah yang serupa.

Ulman (1956) mengelompokkan karakteristik hubungan fungsional antar wilayah menjadi tiga kategori yaitu: proses hubungan yang bersifat Complementarity, Intervening Opportunity dan Transferability antar wilayah atau pulau-pulau.

Proses Complementarity, adalah hubungan yang terjadi antara dua wilayah sebagai akibat adanya suatu proses saling melengkapi satu dengan lainnya, dimana wilayah yang satu men-suply demand dari wilayah lainnya. Proses Intervening Opportunity, adalah hubungan yang terjadi antara satu wilayah dengan wilayah lainnya sebagai akibat adanya tawaran yang lebih menguntungkan dibandingkan wilayah lainnya. Proses Transferability, adalah hubungan yang terjadi antar dua wilayah sebagai akibat adanya infrastruktur yang menghubungkan kedua wilayah tersebut.

Pertumbuhan ekonomi merupakan salah satu tolak ukur untuk menilai perkembangan ekonomi suatu Negara. Pertumbuhan ekonomi dapat diartikan sebagai perkembangan kegiatan dalam perekonomian yang menyebabkan barang dan jasa yang diproduksikan dalam masyarakat bertambah, atau dengan kata lain pertumbuhan ekonomi adalah perkembangan batas kemungkinan produksi (production possibility frontier $=P P F)$ suatu negara (Samuelson,1996).

Menurut Sukirno (2008), pertumbuhan ekonomi berarti perkembangan fisikal produksi barang dan jasa yang berlaku di suatu Negara. Sedangkan menurut Samuelson dan Nordhaus (2004) pertumbuhan ekonomi adalah gambaran ekspansi GDP potensial atau output nasional Negara. Sehingga dapat disimpulkan bahwa pertumbuhan ekonomi merupakan suatu proses peningkatan pendapatan nasional suatu Negara dalam waktu tertentu atau periode tertentu.

Menurut Todaro (dikutip dari Tambunan, 2001) sampai akhir tahun 1960, para ahli ekonomi percaya bahwa cara terbaik untuk mengejar keterbelakangan ekonomi adalah dengan meningkatkan laju pertumbuhan ekonomi setinggi-tingginya sehingga dapat melampaui tingkat pertumbuhan penduduk. Dengan cara tersebut, angka pendapatan per kapita akan meningkat sehingga secara otomatis terjadi pula peningkatan kemakmuran masyarakat dan pada 
akhirnya akan mengurangi jumlah penduduk miskin.

\section{Hubungan Konektivitas Dengan Pertumbuhan Ekonomi}

Selain berdampak terhadap perbedaan harga yang berpotensi pada terjadinya inflasi dan deflasi, konektivitas sangat mempengaruhi proses distribusi barang dalam suatu daerah. Jika distribusi barang dan jasa lancar maka akan memiliki efek positif terhadap kegiatan pembangunan ekonomi daerah tersebut. Seluruh kebutuhan bahan pokok yang dibutuhkan masyarakat akan terjamin ketersediaannya di pasar sehingga akan mengamankan tingkat konsumsi, perbedaan harga antar pulau/daerah tidak begitu besar, inflasi rendah, sehingga berdampak secara positif terhadap pertumbuhan ekonomi daerah. Sebaliknya jika konektivitas antar wilayah masih buruk maka dipastikan tidak terlalu berdampak pada pertumbuhan ekonomi.

\section{Inflasi}

Inflasi adalah suatu gejala di mana tingkat harga umum mengalami kenaikan secara terusmenerus. Kenaikan tingkat harga umum yang terjadi sekali waktu saja tidaklah dapat dikatakan sebagai inflasi. (Nanga, 2001:237).

Sementara itu, menurut Rahardja (1997), inflasi adalah kecenderungan dari harga-harga untuk meningkat secara umum dan terus-menerus. Kenaikan harga dari satu atau dua barang saja tidak disebut inflasi, tetapi jika kenaikan meluas kepada sebagian besar harga barang-barang maka hal ini disebut inflasi.

Secara garis besar ada tiga kelompok teori mengenai inflasi, yaitu: teori kuantitas, teori Keynes dan teori strukturalis. Masing-masing menyoroti aspek-aspek tertentu dari proses inflasi, dan masing-masing bukan teori inflasi yang lengkap yang mencakup semua aspek penting dari proses kenaikan harga ini. Untuk menerapkannya kita harus menentukan aspekaspek mana yang dalam kenyataan penting dimana proses inflasi di suatu negara, dengan demikian teori mana atau kombinasi mana yang lebih cocok. (Budiono, 1990, P : 167-175).

\section{Hubungan Konektivitas Wilayah Dengan Inflasi}

Inflasi merupakan suatu kondisi pasar dimana terjadi pergerakan harga yang cenderung naik dalam kurun waktu tertentu. Pergerakan harga ini umumnya dipengaruhi oleh adanya kenaikan permintaan secara tiba-tiba atau diakibatkan oleh tingginya biaya yang ditimbulkan oleh produk atau barang tersebut seperti biaya produksi, biaya tenaga kerja, biaya transportasi atau pajak. Disamping itu, faktor geografis juga sangat mempengaruhi pergerakan inflasi. Daerah yang berbasis daratan tentu berbeda dengan daerah yang berbasis kepulauan. Daerah dengan infrastruktur yang baik akan lebih efisien dalam mendistribusikan produknya dibandingkan dengan daerah yang minim infrastruktur. Apalagi buat daerah-daerah yang berbasis pulau dan kepulauan maka tantangan untuk mengendalikan inflasi adalah tidak mudah. Dibutuhkan beberapa strategi untuk meredam laju kenaikan inflasi. Khusus untuk provinsi Maluku Utara, Inflasi yang tinggi tentunya tidak baik bagi perekonomian, karena akan mengganggu konsumsi masyarakat, daya beli akan menurun sehingga berpengaruh pada dispossible income.

\section{Kemiskinan}

Kemiskinan Menurut Badan Pusat Statistik (BPS, 2016) adalah ketidak mampuan individu dalam memenuhi kebutuhan dasar minimal untuk hidup layak. Pengertian lainnya kemiskinan merupakan sebuah kondisi yang berada dibawah garis nilai standar kebutuhan minimum, baik untuk makanan dan non makanan, yang disebut garis kemiskinan (proverty line) atau batas kemiskinan. Menurut para ahli Kemiskinan itu bersifat Multi Dimensional, Artinya, karena kebutuhan manusia itu bermacam - macam, maka kemiskinan pun memiliki banyak aspek. Dilihat dari kebijak umum, maka kemiskinan memiliki aspek primer yang berupa miskin akan aset, organisasi sosial politik, dan pengetahuan serta keterampilan dan aspek sekunder yang berupa miskin akan jaringan sosial, sumber - sumber keuangan dan informasi. Dimensi - dimensi kemiskinan tersebut ermanifestasikan dalam bentuk kekurangan gizi, air, perumahan yang sehat, perawatan kesehatan yang kurang baik, dan tingkat pendidikan yang rendah (Arsyad, 2010).

Ada banyak penjelasan mengenai sebab-sebab kemiskinan. Sharp, et al. (1996) dan Kuncoro (2003) mencoba mengindentifikasikan faktorfaktor penyebab kemiskinan dipandang dari sisi ekonomi, yaitu :

a) Secara Mikro, kemiskinan muncul karena adanya ketidaksamaan pola kepemilikan 
sumber daya yang menimbulkan distribusi pendapatan yang timpang. Penduduk miskin hanya memiliki sumber daya dalam jumlah terbatas dan kualitasnya rendah.

b) Kemiskinan timbul akibat perbedaan dalam kualitas sumber daya manusia. Kualitas sumber daya manusia yang rendah berarti produktivitasnya rendah, yang pada gilirannya upahnya rendah.

c) Kemiskinan muncul akibat perbedaan akses dalam modal. Ketika penyebab kemiskinan ini bermuara pada teori lingkaran kemiskinan (vicious circle of poverty).

\section{Hubungan Pertumbuhan Ekonomi dan Tingkat Kemiskinan}

Menurut Kuznets (1955), pada tahap awal pembangunan akan ditandai adanya pertumbuhan yang tinggi dengan disertai tingkat ketimpangan pendapatan dan kemiskinan yang tinggi pula. Kondisi tersebut akan berlangsung sampai pada titik kritis tertentu, di mana tingkat pertumbuhan ekonomi yang tinggi akan diikuti oleh semakin menurunnya tingkat ketimpangan pendapatan dan kemiskinan (Subandi, 2011).

Mengikuti hipotesis Kuznets, pada tahap awal dari proses pembangunan, tingkat kemiskinan cenderung meningkat, dan pada saat mendekati tahap akhir dari pembangunan jumlah orang miskin berangsur-angsur berkurang. Banyak faktor lain selain pertumbuhan pendapatan yang juga berpengaruh terhadap tingkat kemiskinan di suatu wilayah/Negara, seperti derajat pendidikan tenaga kerja dan struktur ekonomi.

Studi-studi empiris lainnya yang juga membuktikan adanya suatu relasi negatif (tradeoff) yang kuat antara laju pertumbuhan pendapatan dan tingkat kemiskinan adalah dari Deininger dan Squire (1995-1996). Studi mereka ini yang juga memakai data lintas Negara sangat menarik karena tidak menemukan suatu keterkaitan yang sistematis walaupun relasi antara pertumbuhan PDB dan pengurangan kemiskinan positif. Lainnya, misalnya hasil penelitian dari Ravallion dan Chen (1997) yang menggunakan data dari survei-survei pendapatan/pengeluaran konsumsi rumah tangga (RT) di 67 NSB dan Negara-negara transisi untuk periode 1981-1994 juga menunjukan bahwa penurunan kemiskinan hampir selalu berbarengan dengan peningkatan pendapatan rata-rata per kapita atau standar kehidupan, dan sebaliknya kemiskinan bertambah dengan kontraksi ekonomi. Hasil plot antara perubahan laju kemiskinan (dalam log) dengan rata-rata atau nilai tengah dari pengeluaran konsumsi atau pendapatan antarsurvei menunjukan suatu tren yang negatif. Sedangkan hasil studi empiris yang dilakukan oleh Mills dan Pernia (1993) dengan metode yang sama (analisis lintas Negara) menunjukan bahwa kemiskinan di suatu Negara akan semakin rendah jika laju pertumbuhan ekonominya pada tahun-tahun sebelumnya tinggi, dan semakin tinggi laju pertumbuhan PDB semakin cepat turunnya tingkat kemiskinan. Juga, studi yang dilakukan oleh Wodon (1999) dengan memakai data panel regional untuk kasus Bangladesh menunjukan bahwa pertumbuhan ekonomi mengurangi tingkat kemiskinan, baik di daerah perkotaan maupun daerah pedesaan.

Hubungan antara pertumbuhan ekonomi atau peningkatan output dan kemiskinan menghasilkan suatu dasar kerangka pemikiran, yakni efek trickle-down dari pertumbuhan ekonomi dalam bentuk peningkatan kesempatan kerja atau pengurangan pengangguran dan peningkatan upah/pendapatan dari kelompok miskin. Dengan asumsi bahwa ada mekanisme yang diperlukan untuk memfasilitasi trickledown dari keuntungan dari pertumbuhan ekonomi kepada kelompok miskin, pertumbuhan ekonomi bisa menjadi suatu alat yang efektif bagi pengurangan kemiskinan.

\section{METODE PENELITIAN}

Penelitian peran konektivitas dalam pembangunan ekonomi kepulauan dilakukan di Provinsi Maluku Utara. Data sekunder panjang jalan, inflasi, pertumbuhan ekonomi, dan kemiskinan periode 2002-2018 diperoleh secara dokumentasi dari kantor badan pusat statistik Provinsi Maluku Utara .

Penelitian ini menggunakan metode analisis jalur (path analysis) untuk menjelaskan hubungan sebab akibat antara satu variabel dengan variabel. Sistem hubungan sebab akibat tersebut mencakup dua jenis variabel yaitu variabel penjelas, biasa di notasikan $X_{1}, X_{2}, \ldots, X_{n}$, dan variabel yang dijelaskan yakni $Y_{1}, Y_{2}, \ldots, Y_{n}$. Dalam model persamaan struktural linear pengaruh variabel $\mathrm{X}$ terhadap $\mathrm{Y}$ dapat berupa pengaruh langsung dan tidak langsung. Pengaruh tidak langsung dari suatu variabel $\mathrm{X}$ terhadap variabel $\mathrm{Y}$ adalah melalui variabel lain yang disebut intervening variable atau variabel antara lainnya (Daryanto dan Hafizrianda, 2012). 
Variabel panjang jalan dinotasikan $\mathrm{X}_{1}$, inflasi adalah $\mathrm{Y}_{1}$, pertumbuhan ekonomi adalah $\mathrm{Y}_{2}$, dan kemiskinan adalah $\mathrm{Z}$ sehingga persamaan struktural dari model jalur sebagai berikut:

Inflasi $\left(\mathrm{Y}_{1}\right)=p_{x l y l} \mathrm{Y}_{1} \mathrm{X}_{1}+\mu 1$

Pertumbuhan ekonomi $\left(\mathrm{Y}_{2}\right)$

$=P_{x l y 2} \mathrm{Y}_{2} \mathrm{X}_{1}+P_{Y l y 2} \mathrm{Y}_{2} \mathrm{Y}_{1}+\mu 2$

Kemiskinan $(\mathrm{Z})$

$=P_{x 12} \mathrm{ZX}_{1}+P_{Y 12} \mathrm{ZY}_{1}+P_{Y 22} \mathrm{ZY}_{2}+\mu 3$

Secara konseptual model yang dikembangkan dalam penelitian ini dapat dilihat pada gambar berikut:

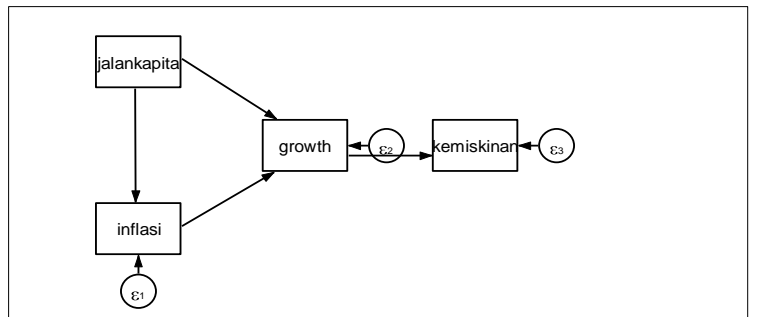

Gambar 3. Hubungan Kausalitas Konektivitas, Inflasi, Pertumbuhan Ekonomi dan Kemiskinan

\section{HASIL DAN PEMBAHASAN}

Tabel 1. Matriks Korelasi

\begin{tabular}{lrrrr}
\hline & Jalan/ & & & \\
& kapita & Inflasi & Growth & Poverty \\
\hline Jalan/ & & & & \\
Kapita & 1 & 0.07 & 0.45 & 0.63 \\
Inflasi & 0.07 & 1 & 0.03 & 0.16 \\
Growth & 0,45 & $-0,03$ & 1 & 0.72 \\
Poverty & $-0,63$ & $-0,16$ & $-0,72$ & 1 \\
\hline
\end{tabular}

Hasil matriks korelasi pada tabel 1 terlihat bahwa hampir semua variabel yang disertakan dalam model jalur memiliki keterkaitan yang kurang kuat satu sama lainnya. Besarnya nilai korelasi semua variabel dibawah $80 \%$. Hubungan yang paling tinggi antara variabel inflasi $\left(\mathrm{Y}_{1}\right)$ dan pertumbuhan ekonomi $\left(\mathrm{Y}_{2}\right)$ yang paling tinggi yaitu sebesar $70,84 \%$ sementara hubungan antar variabel yang paling lemah adalah pertumbuhan ekonomi $\left(\mathrm{Y}_{2}\right)$ dengan inflasi $\left(\mathrm{Y}_{1}\right)$ hanya sebesar $-3,74 \%$. Keterkaitan antar variabel yang lemah menggambarkan bahwa selama kurun waktu periode analisis menyebabkan nilai korelasi rendah sehingga hasil ini mengindikasikan bahwa pelaksanaan kegiatan pembangunan konektivitas di Provinsi Maluku Utara belum efektif dalam pembangunan perekonomian daerah.

Variabel yang berhubungan dengan tingkat kemiskinan memiliki hubungan negatif. Seperti jalan dengan kemiskinan memiliki hubungan negatif sebesar -0,6318, yang menandakan bahwa semakin tinggi tingkat jalan/kapita berarti semakin rendah tingkat kemiskinan. Sebaliknya semakin rendah panjang jalan yang dibangun maka semakin tinggi tingkat kemiskinan. Begitu pula dengan tingkat pertumbuhan ekonomi yang memiliki hubungan negatif terhadap tingkat kemiskinan yaitu -0,7209 dimana semakin tinggi tingkat pertumbuhan ekonomi maka semakin rendah tingkat kemiskinan.

Tabel 2. Koefisien Jalur Model Konektivitas

\begin{tabular}{|c|c|c|}
\hline \multirow[t]{4}{*}{ Inflasi } & Jalankapita & 87.405 \\
\hline & & 0.30 \\
\hline & _cons & 4.969 \\
\hline & & $(3.71)^{* *}$ \\
\hline \multirow[t]{6}{*}{ Growth } & Inflasi & -0.0247 \\
\hline & & $(0.28)$ \\
\hline & Jalankapita & 228.387 \\
\hline & & $2.11^{*}$ \\
\hline & _cons & 5.160 \\
\hline & & $(7.83)^{* *}$ \\
\hline \multirow[t]{8}{*}{ Kemiskinan } & Inflasi & -0.1219 \\
\hline & & -1.07 \\
\hline & Growth & -1.088 \\
\hline & & $-3.51 * *$ \\
\hline & Jalankapita & -358.361 \\
\hline & & $-2.31 *$ \\
\hline & _cons & 18.074 \\
\hline & & 10.00 \\
\hline \multirow[t]{2}{*}{ var (e.inflasi) } & _cons & 11.486 \\
\hline & & $(2.92)^{* *}$ \\
\hline \multirow[t]{2}{*}{ var (e.growth) } & _cons & 1.536 \\
\hline & & $(2.92)^{* *}$ \\
\hline \multirow[t]{2}{*}{$\begin{array}{l}\text { var } \\
\text { (e.kemiskinan) }\end{array}$} & _cons & 2.509 \\
\hline & & $(2.92)^{* *}$ \\
\hline $\mathrm{N}$ & & 17 \\
\hline
\end{tabular}

$* \mathrm{p}<0.05 ; * * \mathrm{p}<0.01$

Model jalur yang dikembangkan berdasarkan hasil matriks korelasi menunjukkan variabel yang signifikan meliputi jalur jalan perkapita dengan pertumbuhan ekonomi, pertumbuhan ekonomi dengan kemiskinan, dan jalan perkapita dengan kemiskinan. Ketiga jalur tersebut memiliki nilai probabilitas t-stat lebih kecil dari 0,05 atau signifikan pada tingkat kepercayaan 95\%. Berdasarkan hasil uji statistik pada tabel 2 , model yang mempunyai tingkat kebermaknaan yang sangat tinggi yaitu jalur 
yang memiliki nilai probabilitas yang signifikan sementara untuk jalur yang memiliki nilai probabilitas di atas nilai t-stat atau tidak signifikan memiliki tingkat kebermaknaan yang rendah. Namun demikian, tanda koefisien variabel pada jalur yang tidak signifikan tetap menunjukkan hubungan yang memiliki makna dalam mengukur pengaruh antar variabel dalam model analisis jalur.

\section{PEMBAHASAN}

Berdasarkan hasil analisis uji statistik, jalur yang memiliki nilai signifikan tinggi dapat menjelaskan pengaruh dari suatu variabel terhadap variabel lainnya baik secara parsial maupun secara serentak. Dengan demikian, model jalur lintasan untuk menjelaskan model hubungan konektivitas dengan inflasi, pertumbuhan ekonomi, dan kemiskinan dapat dilihat pada Tabel 3 dan Gambar 4.

Pada jalur pertama pada Tabel 3, hubungan langsung variabel pembangunan konektivitas dalam bentuk infrastruktur jalan memiliki pengaruh positif terhadap tingkat inflasi. Hasil ini mengindikasikan bahwa pengembangan konektivitas antar wilayah di Provinsi Maluku Utara belum mampu menurunkan tingkat harga barang di pulau. Karakteristik inflasi di Provinsi kepulauan Maluku Utara lebih banyak dipengaruhi oleh tingkat keseimbangan antara jumlah permintaan dan penawaran agregat. Sebagai wilayah kepulauan, salah satu kerentanan ekonomi bagi wilayah pulau-pulau adalah pasar domestik yang kecil sehingga tingkat permintaan barang relatif rendah (Fernandes \& Pinho, 2015). Jumlah permintaan kebutuhan ekonomi masyarakat pulau relatif lebih besar dari barang yang ditawarkan untuk dijual ke luar wilayah. Kemampuan pulau yang rendah untuk menghasilkan produk yang bernilai tambah sehingga memiliki daya saing menjadi hambatan untuk meningkatkan tingkat penawaran. Faktor biaya pengangkutan barang melalui angkutan darat dan laut yang tinggi menyebabkan pembangunan konektivitas belum mampu menurunkan tingkat inflasi di pulau.

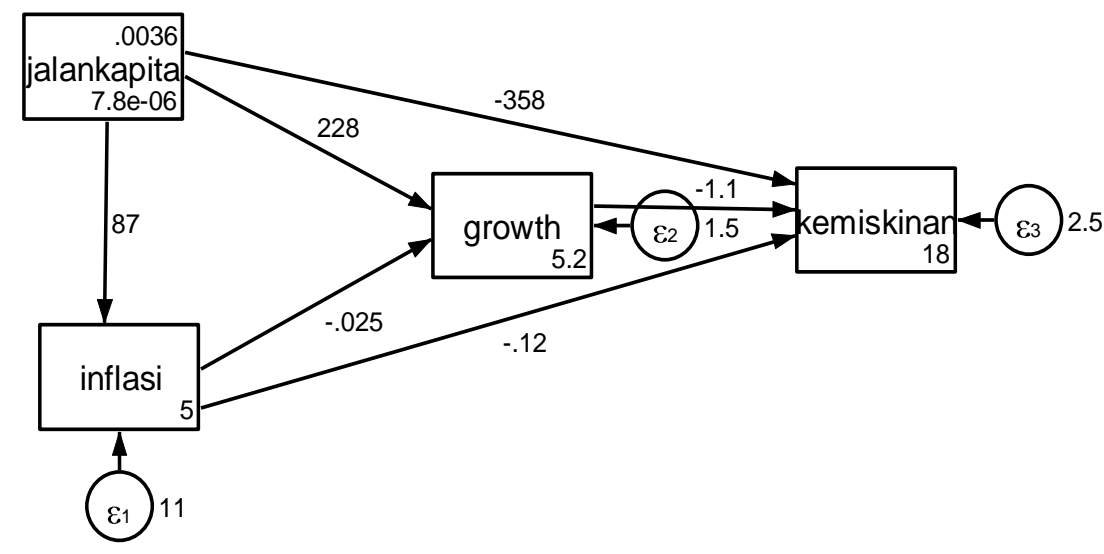

Gambar 4. Hasil Analisis Hubungan Kausalitas Antar Variabel

Tabel 3. Nilai Hubungan Koefisien Model Konektivitas

\begin{tabular}{|c|c|c|c|c|c|c|}
\hline No & & Jalur & Koef. & t-stat & Prob & Hasil \\
\hline 1 & Jalan/kapita & - Inflasi & 87.405 & 0.30 & 0.767 & Tidak Signifikan \\
\hline 2 & Inflasi & - Pertumbuhan Ekonomi & -0.025 & -0.28 & 0.780 & Tidak Signifikan \\
\hline 3 & Jalan kapita & - Pertumbuhan Ekonomi & 228.388 & 2.11 & 0.035 & Signifikan \\
\hline 4 & Inflasi & - Kemiskinan & -0.122 & -1.07 & 0.283 & Tidak Signifikan \\
\hline 5 & Pertumbuhan & Ekonomi - Kemiskinan & -1.089 & -3.51 & 0.000 & Signifikan \\
\hline 6 & Jalan Kapita & - Kemiskinan & -358.361 & -2.31 & 0.021 & Signifikan \\
\hline
\end{tabular}

Sumber: Hasil analisis data, 2020

Jalur kedua yaitu pengaruh langsung inflasi terhadap pertumbuhan ekonomi menunjukkan hubungan negatif tidak signifikan. Walaupun hasil probabilitas pengaruh tersebut belum signifikan, namun setidaknya tanda koefisien korelasi yang negatif mengindikasikan bahwa tingkat inflasi yang tinggi dapat berdampak pada 
penurunan tingkat pertumbuhan ekonomi masyarakat pulau. Tingkat inflasi tinggi di wilayah pulau-pulau memiliki kerentanan terhadap kemampu masyarakat untuk meningkatkan skala produksinya. Harga bahan baku yang relatif tinggi karena di datangkan dari luar wilayah pulau menyebabkan biaya produksi meningkat sehingga harga jual di pasar cenderung mahal. Harga yang tinggi dapat berpengaruh pada kemampuan daya beli masyarakat. Jika daya beli masyarakat pulau rendah maka keseimbangan tingkat permintaan dan penawaran dapat menurun sehingga berimplikasi terhadap penurunan skala produksi, pertumbuhan ekonomi pulau menjadi rendah.

Jalur ketiga, hubungan langsung antara peningkatan konektivitas jalan terhadap pertumbuhan ekonomi menunjukkan pengaruh positif signifikan. Ini menunjukkan bahwa semakin besar peningkatan pembangunan konektivitas dalam bentuk infrastruktur jalan mendorong kegiatan distribusi barang dan jasa berjalan efektif, kegiatan pembangunan di daerah baik secara sektor maupun secara kewilayahan akan lebih berkembang. Proses distribusi yang lancar menjamin kebutuhan primer yang dibutuhkan masyarakat sehingga ketersediaan barang untuk aktivitas konsumsi dan produksi selalu tersedia, dampaknya secara positif akan menigkatkan pertumbuhan ekonomi daerah. Pengembangan konektivitas antar wilayah harus terus di tingkatkan mengingat masih terdapat beberapa wilayah kecamatan yang belum dapat dijangkau dengan transportasi darat dikarenakan infrtastruktur jalan belum layak dan dalam kondisi rusak. Beberapa pulau juga belum dapat menikmati aksessibilitas jalan yang baik sehingga mengganggu proses pengangkutan dan distribusi hasil panen komoditas unggulan petani setempat.

Jalur keempat, pengaruh langsung tingkat inflasi dengan kemiskinan yang menunjukkan hubungan negatif. Hasil ini tidak sesuai dengan hipotesa yang menunjukkan hubungan positif antara inflasi dengan tingkat kemiskinan yaitu jika tingkat inflasi tinggi maka berdampak terhadap peningkatan jumlah orang miskin. Hal tersebut terkait dengan beberapa faktor seperti tingkat upah, jumlah pengangguran, dan jumlah uang beredar. Namun dalam riset ini variabel tersebut tidak dimasukkan dalam model sehingga diasumsikan cateris paribus. Hasil tanda koefisien negatif menjelaskan bahwa variabel inflasi secara langsung belum efektif menurunkan jumlah kemiskinan masyarakat di wilayah kepulauan Provinsi Maluku Utara. Atau dengan kata lain, faktor inflasi tidak berpengaruh terhadap tingkat kemiskinan di Provinsi Maluku Utara.Harga barang yang tinggi di pulau-pulau secara ekonomi menjadi beban bagi masyarakat pulau yang berpendapatan rendah. Walaupun harga barang dijual lebih mahal, masyarakat di pulau hanya mampu membeli kebutuhan pangan pokok yaitu beras. Sedangkan untuk kebutuhan pangan lainnnya seperti sayur dan lauk mereka dapatkan dari hasil kebun dan ikan di laut. Pola hidup konsumsi seperti ini sudah menjadi tradisi masyarakat yang tinggal di pulau-pulau kecil dan wilayah pesisir di Provinsi Maluku Utara. Sehingga dapat dikatakan bahwa beban masyarakat miskin di pulau-pulau atau di pedesaan sangat terpengaruhi dengan hasil produksi lahan perkebunan yang dimiliki.

Jalur kelima, pengaruh langsung pertumbuhan ekonomi dengan kemiskinan menujukkan hubungan negatif dan signifikan. Hasil ini menggambarkan bahwa efek pertumbuhan ekonomi yang tinggi dapat menurunkan jumlah kemiskinan di wilayah pulau dan kepulauan Provinsi Maluku Utara. Selama kurun waktu periode pengamatan, pembangunan ekonomi baik secara sektor maupun spasial pasca pemekaran mengalami kemajuan yang cukup baik dari aspek tingkat penerimaan dan pendapatan dalam bentuk PDRB. Nilai PDRB dari tahun ke tahun yang mengalami peningkatan mendorong tingkat pertumbuhan ekonomi yang relatif tinggi sehingga berkontribusi terhadap penurunan jumlah angka kemiskinan. Jumlah kemiskinan tahun 2015 sebesar $6.84 \%$ turun menjadi $6.77 \%$ di tahun 2019 (BPS Maluku Utara, 2019). Penuruan jumlah kemisinan ini tidak lepas dari tingkat indeks kedalaman kemiskinan yang juga mengalami trend penurunan yaitu pada tahun 2018, indeks kedalaman kemiskinan (IKK) sebesar 0.892 menurun menjadi 0.887 pada tahun 2019. Penurunan ini mengindikasikan bahwa rata-rata pengeluaran penduduk miskin Provinsi Maluku Utara semakin menjauhi garis kemiksinan.

Jalur keenam, pengaruh langsung pembangunan konektivitas jalan terhadap kemiskinan memiliki hubungan negatif dan signifikan. Hasil ini menegaskan bahwa pembangunan konektvitas dalam bentuk infrastruktur jalan berdampak terhadap penurunan jumlah kemiskinan di wilayah Provinsi Maluku Utara. Semakin besar 
peningkatan pembangunan konektivitas antar pulau atau wilayah maka jumlah kemiskinan di Provinsi Maluku Utara dapat menurun.

Peran konektivitas antar wilayah sangat penting dalam pembangunan ekonomi di wilayah kepulauan. Keterisolasian dari lingkungan luar serta dan merupakan wilayah periphery dari pusat ekonomi merupakan salah satu karakteristik kerentanan yang dimiliki oleh wilayah pulau-pulau (Fernandez \& Pinho, 2017). Keterbatasan infrastruktur penunjang transportasi terutama moda transportasi laut akan menimbulkan permasalahan aksessibilitas antar pulau dengan wilayah pusatnya. Efek dari keterisolasian menyebabkan potensi ekonomi pulau sulit berkembang sehingga untuk membuka keterisolasian pulau-pulau kecil, kebijakan pengembangan ekonomi lokal di pulau-pulau kecil perlu ditunjang oleh kebijakan pengembangan jaringan angkutan laut guna mengembangkan potensi sumberdaya yang dimilikinya serta mempermudah aliran barang dan jasa diantara pulau-pulau kecil yang ada.

Masalah lain yang dihadapi oleh masyarakat pulau adalah ketergantungan ekonomi yang tinggi terhadap bantuan dari wilayah luar. Sumberdaya yang terbatas dari pulau-pulau kecil yang relatif sama besar menunjukkan bahwa jika ada keuntungan relatif maka itu hanya terjadi pada sedikit sektor saja. Perdagangan yang dilakukan dengan mitra wilayah kontinentalnya yang lebih kaya berarti bahwa keuntungan yang diperoleh dari spesialisasi komoditas yang diperdagangkan jauh lebih besar pengembaliannya dari usaha sektor ekonomi di pulau lainnya. Akibatnya, ekonomi pulau dapat menjadi cepat terspesialisasi yang tinggi, sehingga mengesampingkan aktivitas lainnya yang tidak terkait. Sebagai contoh spesialiasi pada komoditas pertanian yang diperdagangkan dapat dengan cepat mengurangi produksi pangan untuk konsumsi lokal.

Rendahnya kemampuan pulau-pulau
dibandingkan dengan potensi pasarnya
menunjukkan prospek ekonomi pulau-pulau
memperoleh hasil ekonomi yang jumlahnya
relatif kecil sehingga harga yang diterima di
pasar tidak begitu menguntungkan. Kekurangan
ini memiliki dampak secara luas yaitu
pendapatan yang diperoleh oleh masyarakat
pesisir di pulau-pulau tidak mencukupi untuk
memenuhi kebutuhan hidup sehari-hari. Dalam
hal ini Kerr (2005) menyatakan keuntungan

relatif tersebut sangat tergantung pada permintaan, fungsi selera, pendapatan ril, ketersediaan dan biaya pengganti; kemampuan pulau untuk menjangkau konsumen, yaitu fungsi fisik dan kebijakan untuk mengakses pasar; penawaran dan harga yang berasal para pesaing.

Oleh karena keterbatasannya dalam skala ekonomi yang cenderung kecil, maka pengembangan pulau kecil harus mampu menciptakan suatu proses transformasi sosial maupun ekonomi. Masyarakat di pulau-pulau kecil harus dapat diberdayakan secara ekonomi, sosial, dan budaya, maka kebijakan pengembangan pulau-pulau kecil harus ditekankan pada kekuatan sumberdaya lokal yang bertujuan untuk mengurangi biaya transportasi, menghasilkan proses diversifikasi produk yang tinggi sehingga terjadi transaksi perdagangan dengan keragaman produk dengan daerah lain, menciptakan produk berbasis pada masyarakat dan pengetahuan lokal agar tercipta interdependensi ekonomi lokal dalam konteks ekonomi global (Kusumastanto 2003).

\section{KESIMPULAN}

1. Konektivitas antar wilayah yang baik, menunjang proses kegiatan ekonomi daerah semakin berkembang. Hasil menunjukkan bahwa peningkatan konektivitas secara positif dapat meningkatkan pertumbuhan ekonomi dan menurunkan tingkat kemiskinan di wilayah kepulauan Provinsi Maluku Utara. Selain itu pertumbuhan ekonomi yang tinggi secara positif dan signifikan mampu menurunkan jumlah kemiskinan wilayah pulau.

2. Faktor ketersediaan dan mahalnya harga bahan bakar minyak menjadi kendala utama bagi pengembangan transportasi untuk menunjang konektivitas antar pulau-pulau yang dijadikan tempat destinasi wisatawan baik lokal maupun mancanegara. Sehingga dampak sektor pariwisata terhadap peningkatan pendapatan dan pertumbuhan ekonomi daerah sangatlah kecil. Sementara dampak konektivitas terhadap sektor pertanian juga masih kecil. Keterbatasan sarana pendukung lainnya seperti dermaga di pulau-pulau kecil dan desa-desa pesisir menjadi penghambat bagi kapal untuk bisa sandar untuk mengangkut hasil produksi para petani. Sektor perikanan belum bisa memberikan kontribusi yang tinggi pada pertumbuhan ekonomi hal ini disebabkan 
karna jumlah hasil tangkapan yang tergolong masih rendah ini dan minimnya jumlah kapal yang dapat melayani pulau-pulau terpencil.

\section{SARAN KEBIJAKAN}

Pembangunan konektivitas antar pulau dan wilayah dapat menunjang peningkatanpertumbuhan ekonomi dan mampu menurunkan angka kemiskinan di wilayah pulau-pulau dan kepulauan Provinsi Maluku Utara. Karena itu, percepatan pembangunan infrastruktur jalan lingkar di beberapa pulaupulau kecil yang belum terhubung antar desa dapat segera diwujudkan demi kelancaran proses distribusi jasa dan barang kebutuhan ekonomi masyarakat pulau. Penyediaan sarana transportasi laut yang lebih beragam untuk konektifitas antar pulau-pulau dan desa-desa pesisir yang belum terjangkau juga sangat mendesak untuk direalisasikan. Pengaturan jalur tata niaga perdagangan antar pulau yang lebih efisien serta pengembangan pusat industri pengolahan hasil komoditas unggulan pulau seperti pengolaha ikan dan industri pengolahan hasil perkebunan di kota Ternate, Bacan, dan Morotai sehingga kegiatan ekspor dapat dilakukan secara langsung kenegara luar melalui pelabuhan-pelabuhan di wilayah Provinsi Maluku Utara.

\section{DAFTAR PUSTAKA}

Arsyad, Lincolin. 2010. Ekonomi pembangunan. Edisi 5 .Yogyakarta: STIM YKP

Badan Statistik Propinsi Maluku Utara. Berbagai Tahun Publikasi. Propinsi Maluku Utara Dalam Angka. BPS Propinsi Maluku Utara.Maluku Utara.

Bandarin, F., Hosagrahar, J., \& Albernaz, F. S. 2011. "Why development needs culture". Journal of Cultural Heritage Management and Sustainable Development, 1 (1), 1525.

Barro, R.J. and X. Sala-i-Martin. 1995. Economic Growth, McGraw-Hill, Inc., New York.

Behrens, K. (2007). Regional economics: A new economic. Regional Science and Urban Economics, 37, 457-465.

BPS Maluku Utara. (2019). Profil Kemiskinan
Provinsi Maluku Utara 2019.

Fernandez, R., \& Pinho, P. (2017). The distinctive nature of spatial development on small islands. Progress in Planning, 112, $1-18$.

Harmes. 2018. Model Pembangunan Wilayah Berbasis Penanggulangan Kemiskinan Di Kota Bengkulu. Bogor : Sekolah Pascasarjana IPB.

Ismiaji, Risky \& A.Wardhana. 2014. Why Indonesia Needs Low -Cost- Carriers to Boost Its Tourism Sector? Paper of annual IRSA Conference.

Kerr, S. A. 2005. What is small island sustainable development about? Ocean and Coastal Management, 48(7-8), 503-524. https://doi.org/10.1016/j.ocecoaman.2005.0 3.010

Kuncoro, Mudrajad. 2012. Perencanaan Daerah : Bagaimana Membangun Ekonomi Lokal, Kota dan Kawasan? Salemba Empat. Jakarta.

Keith Hartley \& William J. Corcoran. 1975. Short-run employment functions and defence contracts in the UK aircraft industry, Applied Economics, 7:4, 223233, DOI: 10.1080/00036847500000023.

Lösch, A. 1938. "The nature of economic regions", Southern Economic Journal, 5: 71-78.

Novegya Ratih Primandari. 2018. Pengaruh pertumbuhan ekonomi, inflasi dan pengangguran terhadap tingkat kemiskinan di Sumatera Selatan. Jurnal Ekonomi Pembangunan, Vol. 16 (1): 1-10, Juni 2018. Fakultas Ekonomi, Universitas Baturaja, Sumatera Selatan.

Prahara, Guntur. (2010). Analisis Disparitas Antar Wilayah terhadap Pertumbuhan Ekonomi Provinsi Kalimantan Barat. Bogor: Sekolah Pascasarjana Institut Pertanian Bogor

Rana, Irfan Ahmad. (2017). The Spatial and Temporal Dynamics of Infrastructure Development Disparity - From Assessment To Analyses. Journal: Cities Volume: 63.

Richardson, H., W., (1977). Dasar-dasar Ilmu Ekonomi Regional, (terjemahan paul Sihotang), Lembaga Penerbitan, FE-UI, 
Jakarta.

Soepono, Prasetyo. 2000. "Model Gravitasi sebagai alat pengukur hinterland dari Central Place",Jurnal Ekonomi dan Bisnis Indonesia, Vol.15 No. 4, 414-423.

Subandi. 2012. Ekonomi Pembangunan. Bandung: Alfabeta.

Sukirno, S.1985. Ekonomi Pembangunan: Proses, Masalah dan Dasar Kebijakan. Lembaga Penerbit Fakultas Ekonomi Universitas Indonesia, Jakarta.

Sukwika, Tatan. 2018. Peran Pembangunan
Infrastruktur terhadap Ketimpangan Ekonomi Antarwilayah di Indonesia. Jurnal Wilayah dan Lingkungan. Volume 6 Nomor 2. Agustus 2018.

Todaro, Michael P. 2000. Pembangunan Ekonomi di Dunia Ketiga, Penerbit Erlangga, Jakarta.

Wahyuni, Krismanti Tri. 2011. Konvergensi dan Faktor-Faktor yang Mempengaruhi Ketimpangan Wilayah Kabupaten/Kota di Pulau Jawa. Bogor: Sekolah Pasca Sarjana Institut Pertanian Bogor. 